\title{
Striving Toward a Circular Economy for Phosphorus: The Role of Phosphate Rock Mining
}

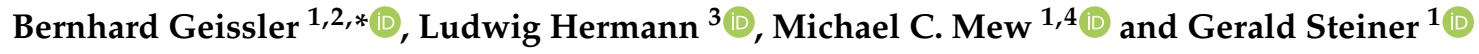 \\ 1 Department of Knowledge and Communication Management, Danube University Krems, \\ Dr. Karl-Dorrek-Straße 30, 3500 Krems, Austria; michaelmew99@gmail.com (M.C.M.); \\ gerald.steiner@donau-uni.ac.at (G.S.) \\ 2 Faculty of Geosciences, University of Resources TU Bergakademie Freiberg, Geoengineering and Mining, \\ Akademiestraße 6, 09599 Freiberg, Germany \\ 3 Proman Management GmbH, Weingartenstrasse 92, 2214 Auersthal, Austria; 1.hermann@proman.pro \\ 4 CRU International, Chancery House, 53-64 Chancery Lane, London WC2A 1QS, UK \\ * Correspondence: bernhard.geissler@donau-uni.ac.at
}

Received: 30 July 2018; Accepted: 5 September 2018; Published: 8 September 2018

\begin{abstract}
As an element, phosphorus (P) is one of a kind. While it is essential for all life on Earth, phosphorus is neither substitutable nor infinite especially in terms of highly concentrated phosphate rock deposits. Society as a whole-and key stakeholders in particular-must build on and extend the idea of a linear system that begins with exploration, continues with extraction and processing, and ends with the application of fertilizers, by applying mechanisms of circularity. The efficient and sustainable utilization of $P$ including intra-generational and intergenerational fairness requires the recognition of its dissipative structure as an important first step. With its Manifesto for a Resource-Efficient Europe, the European Commission acknowledged the inevitability of the transition toward a regenerative Circular Economy (CE). The concept of a CE evolves around the avoidance of losses, which can be found all along the $\mathrm{P}$ supply chain in varying degrees of magnitude and leads to total nutrient-use efficiencies as low as $5 \%$ to $10 \%$. This makes $\mathrm{P}$ a prime target for moving toward a circular economy. While common state-of-the-art work addresses mostly the loop (i.e., production, use, collection, and recycling) itself, we are discussing the current role of raw materials "feeding" the loop with respect to the mining phase. From a resilience perspective, the aim must be to keep every $\mathrm{P}$ atom flowing and circulating within our economy for as long as possible. Hereby, every measure needs to be considered under the principle of proportionality in terms of sustainable development. Therefore, changes to the current approach in the form of multidimensional innovation (e.g., products, processes, and structures) must be considered from various perspectives including technological, geological, and economic aspects. The economic framework conditions, in particular, determine the cut-off between valuable product and "waste". We build our arguments on the "Phosphate Rock Mining-Innovation Nexus" and illustrate potential best-practice examples.
\end{abstract}

Keywords: sustainable mineral economics; resource efficiency; sustainable mining; circular economy; resource management; policy-making; phosphate rock mining; system innovation

\section{Introduction}

In contrast to currently dominating linear extractive industrial models, circular principles are those that close loops through reuse and recycling usually all along the supply chain to ultimately form "circular supply chains" [1]. Thus, there is a need for innovations of all kinds that aim at closing loops and simultaneously reducing negative environmental or societal impacts as part of a sustainable system transition. Given its special properties, the latter considerations are particularly important 
for the case of phosphorus $(\mathrm{P})$. Representing one of the major macronutrients, $\mathrm{P}$ is a critical building block for today's mineral fertilizers and, thereby, for global food security. Although, P is essential for all life on earth. On the other hand, its excessive use causes massive environmental pollution including eutrophication and long-term soil infertility. Furthermore, $\mathrm{P}$ is non-substitutable and has a dissipative use structure. These unique characteristics make promoting a more sustainable utilization of P inevitable [2].

Phosphorus is produced almost exclusively through the mining of finite phosphate rock (PR) deposits of either sedimentary $(87 \%)$ or igneous $(13 \%)$ origin. From the overall production volume, $83 \%\left(46 \mathrm{Mt}_{2} \mathrm{O}_{5}\right)$ is used for chemical fertilizers and the rest is used for other industrial purposes [3]. The currently mostly linear P supply chain includes exploratory activities, extraction (mostly open-pit), and beneficiation (depending on the ore characteristics, typically consisting of screening, separation, and flotation), processing to produce fertilizers of various kinds (primarily through the production of wet phosphoric acid, WPA), and consumption in the form of phosphate fertilizers (PF). Once applied as a fertilizer, $\mathrm{P}$ is taken up by plants. The rest remains as a stock in the soil from where parts are leached into our aquatic system and become sediments. End-of-pipe solutions are used by recycling mostly organic P in sewage sludge and manure (e.g., [4]) or in the form of inorganic struvite (e.g., [5]). A more detailed breakdown of the overall supply chain can be found in Steiner et al. [6]. Nevertheless, the potential for an efficiency increase is available all along the supply chain since currently P losses amount to up to $95 \%$ (from PR-ore to human consumption [2,7]).

Our primary focus with this manuscript is the PR mining phase including extraction and beneficiation. Beneficiation ratios (efficiency of the upgrade process from PR-ore to marketable concentrate, i.e., PR-M) average 67.2\% on a global level [6]. Mining rates (defined as the ratio of actually recovered PR-Ore to the tonnage outlined in the mine plan [7]) are harder to quantify given that the input amount is typically not exactly known. Estimates suggest rates of approximately $90 \%$ [8]. Measures have been taken to increase rates and potential future measures are manifold. However, from a sustainability-related perspective, changes to and/or adaptions of the current system typically require trade-offs, which means that, for example, the introduction of a flotation plant to PR beneficiation will increase the amount of $\mathrm{P}$ extracted but, at the same time, will also require additional amounts of water, energy, and chemicals. Sustainability cost-benefit analysis could help to identify the best long-term alternative. Although originally introduced for the evaluation of fertilizer subsidy policies, a conceptual, multilevel environmental and sustainability assessment provided by Scholz and Geissler [9] might serve as a starting point. Process steps such as transporting marketable concentrates of phosphate rock over long distances by truck or train often account for avoidable losses. For instance, the Moroccan office of Chérifien des Phosphates (OCP Group, OCP SA) built a slurry pipeline to connect the extraction and beneficiation sites with their downstream plants in order to address this issue of transportation losses (in addition to other concerns). On the level of radical process and product innovation, JDC Phosphate addresses issues of reducing contamination and using low-grade ore. Such measures are examples of how innovations can contribute to a more sustainable use of finite raw materials. While slurry pipelines represent technology-based (for the most part beneficial) process innovations, further innovations on product, structure, or social life are equally important. PR seabed mining represents a more controversial potential innovation. While it can be seen as a feasible source for the future PR supply, it raises significant concerns about potential environmental impacts to the aquatic ecosystem. Case 4 (Yara's paste thickener) represents a further technology-based innovation that (in addition to others) also affects the safety of residents close to mine sites since it reduces the risk for failing tailing-pond dams.

\subsection{Circular Economy: Thoughts and Considerations}

Economy is defined as (1) "the structure or conditions of economic life in a country, area, or period; also: an economic system" respectively (2a) as the "thrifty and efficient use of material resources: 
frugality in expenditures; also: an instance or a means of economizing" [10] or, in other words, economy is a localized real-world system based on the assumption of rational choice.

Besides national governments such as China, Japan, and Canada, the EU represents a major driving force in the promotion of a CE [11]. The European Commission has adopted a CE work package indicating that: "the transition to a more circular economy, where the value of products, materials, and resources is maintained in the economy for as long as possible, and the generation of waste minimized, is an essential contribution to the EU's efforts to develop a sustainable, low carbon, resource efficient, and competitive economy" [12]. In general, the concept of current CE considerations has been developed and led almost exclusively by practitioners including policy-makers, business consultants, business associations, and foundations [13]. A solid scientific embeddedness is difficult to identify since the CE is based loosely on a broad variety of scientific fields. De Jesus et al. [14] identified related concepts such as industrial symbiosis, zero waste, natural capitalism, cradle-to-cradle design, and industrial ecology. The latter, in particular, goes back as far as the late 1980s and 1990s with concepts such as the Styrian Kreislaufwirtschaft, Hamburger Cradle to Cradle design concept, and Kalundborg that aimed to bridge science and practice. Korhonen et al. [11] suggested the established field of ecological economics as a proper place for scientific groundwork. These authors consider the business concept of a CE from a sustainable development perspective and suggest the following definition, upon which we also base our research: "Circular economy is an economy constructed from societal production-consumption systems that maximizes the service produced from the linear nature-society-nature material and energy throughput flow. This is done by using cyclical materials flows, renewable energy sources, and cascading-type energy flows. A successful circular economy contributes to all the three dimensions of sustainable development. A circular economy limits the throughput flow to a level that nature tolerates and utilizes ecosystem cycles in economic cycles by respecting their natural reproduction rates" [11]. A broad set of additional definitions originating from scientific literature was recently compiled by Prieto-Sandoval et al. [15] and analyzed by Kirchherr et al. [16] In addition, as CE is gaining attention, several review papers emerged within the last several years (e.g., see [17-22]).

Based on the above, we may conclude that a circular economy represents a desired state for a future economy comparable and in line with the goal of a sustainable economy while the regional context/system boundary of an economy might be extended/changed to further contexts (e.g., agricultural or P economy). Nevertheless, to reach this target state, we have to think about strategies to operationalize this goal. In order to do so, the economics' toolbox already comprises certain measures often referred to as circular principles (e.g., [23]), circular use (e.g., [12]), or circular supply chains including closed-loop and reverse logistics [1].

Subsequently, Figure 1 is a common way to express the idea of a CE in a very simplified manner. It shows the major steps along a common supply chain (SC), whereby circulation is limited strictly to recycling. In order to move from the current linear economy toward a $\mathrm{CE}$, two major types of change or innovation agents will be required. On a microeconomic level, consumers and firms will need to change certain behaviors since they are considered the driving actors. Second, on a macroeconomic level, policy-making authorities on various levels ranging from local to regional up to national and, finally, the supranational level will be needed to establish a framework to enable a CE.

Although somewhat indicated in Figure 1, a CE is not limited to recycling. However, especially for metals, energy use (including associated air emissions) and water use are typically much lower for the processing of secondary raw materials (i.e., scrap) than for primary production [24]. Nevertheless, we must be aware that $100 \%$ recycling rates will always be hypothetical given the laws of thermodynamics. Further benefits might include lower impacts to the biosphere (e.g., rainforests, Arctic regions, or ocean floors), societal implications (e.g., new jobs, health impacts), and geopolitical consequences in the form of an increased supply security for import-dependent regions. Nevertheless, phosphates are fundamentally different from metals. Therefore, Section 2 focuses solely on PR mining and its role toward a P circular economy. 


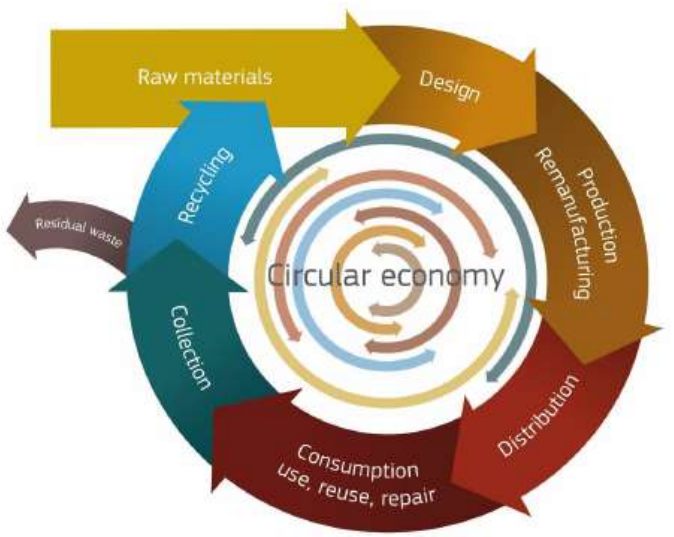

Figure 1. Conceptional diagram illustrating a CE in a simplified manner [12].

\subsection{Innovation as the Vehicle to Attain a Circular Economy}

Multidimensional innovation is essential for improving $\mathrm{P}_{2} \mathrm{O}_{5}$ recovery, the utilization of waste, and the recovery of by-products within the boundaries of sustainable development $[25,26]$. Therefore, sustainable system innovation is a multidimensional concept that encompasses products, processes, and structures as well as various agents along the supply chain in addition to the society and becomes the vehicle and key mechanism in striving for a circular economy (see right part of Figure 2).

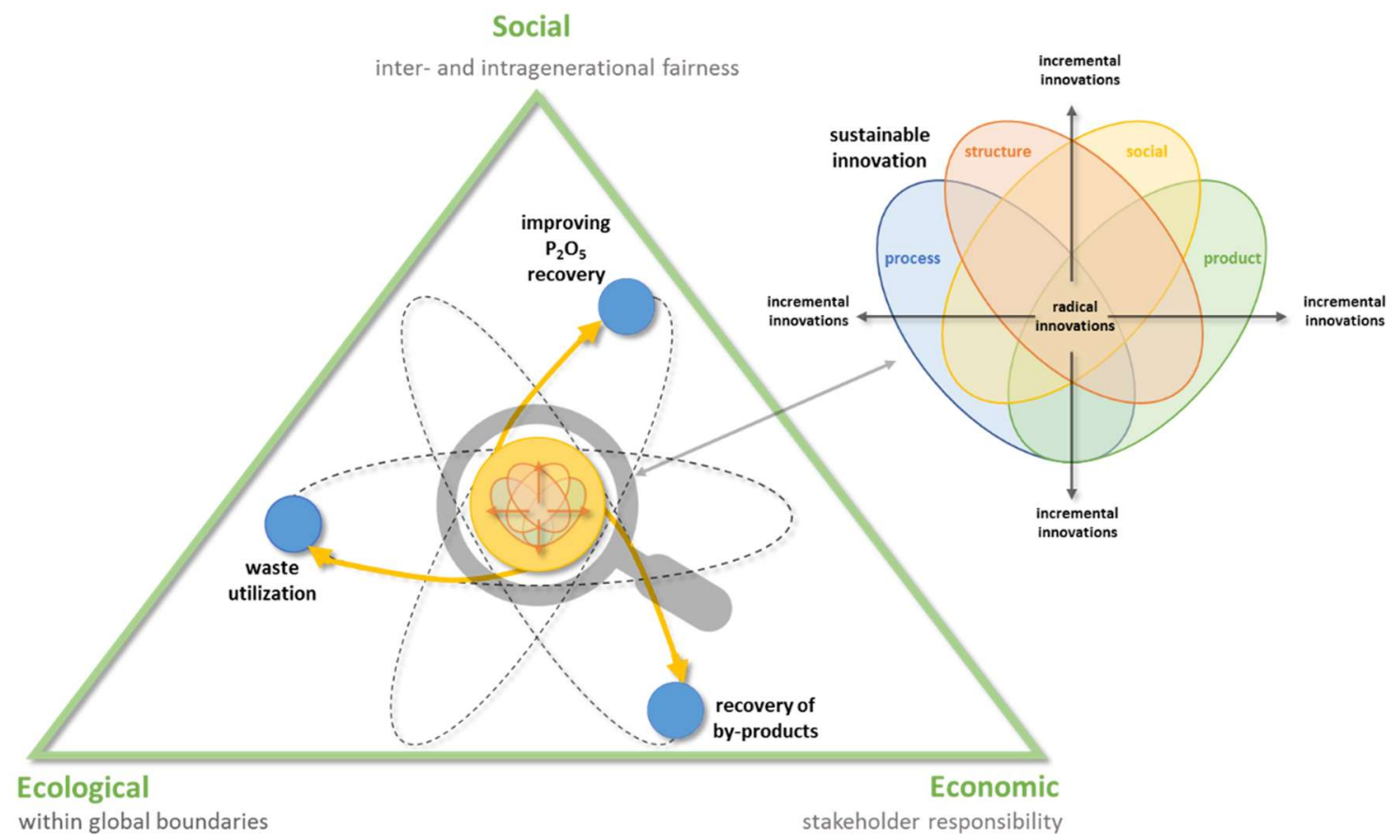

Figure 2. The Phosphate Rock Mining-Innovation Nexus of sustainable phosphorus management based on [26].

To make this contribution, innovation needs to be based on the understanding of the underlying system mechanisms (i.e., mining as part of the phosphorus supply chain), of potential vulnerabilities (e.g., losses, pollution) and opportunities (e.g., efficiency improvements), and of the effects of innovations as intervention that are directed toward sustainable transition and increased system resilience (e.g., [27,28]). Hereby, dynamic change and adaptation characterize the system of consideration, its environment, and the innovation itself, but both also depend on the experience and perception (as a mental simulation of innovation effects) of the observer. This implies that not only functional trade-offs might occur (e.g., as described in the case section), but also trade-offs between 
the various agents involved (e.g., inventors, innovators, and entre-/entrepreneurs) as well as other stakeholders. In the sense of J.A. Schumpeter [29], innovation is often related to creative destruction, i.e., some agents will be better off because of the implementation of a new technology, while others will be worse off (particularly those who relied on the inferior technology). It is also important to consider the role of technology within this context since it is different from process or product innovation (at least in the German speaking innovation school $[30,31])$. We consider technology as an enabler and, therefore, as a preliminary stage rather than a finished product or process since it provides the opportunity to be transformed.

\subsection{Mining and Society}

In its latest version of the World Mining Data [32], the Austrian Federal Ministry for Sustainability and Tourism reports a world mining production of 16.9 billion metric tons (excluding construction materials and bauxite) in 2016. This is an almost 50\% increase from 2000 (11.3 billion metric tons) and close to $75 \%$ from 1985 (9.7 billion metric tons). Besides Europe (-17.7\%), all other world regions show increasing growth rates ranging from 126.5\% (Oceania), 94.6\% (Asia), 28.8\% (Latin America), and $19.2 \%$ (Africa) to $4.3 \%$ (North America). From a country's state of development perspective (based on OECD criteria), $1.3 \%$ is mined in the least developed countries, $59.3 \%$ in developing countries, $12.7 \%$ in transitioning countries, and only $26.8 \%$ is mined by developed countries. Furthermore, almost two-thirds of the overall volumes is mined in extremely unstable $(4.4 \%)$ or unstable (62\%) countries.

All of the information above highlights two main issues. First, mining volumes are constantly rising and, second, mining is continuously shifting away from Western society. The latter follows the perception of mining as being a devastating and dirty business [33], which is frequently justified. Developed societies especially try to avoid having mines or anything related close to its 'own backyard' (i.e., NIMBY syndrome; not in my backyard).

Given the increasing globalization of commodity markets, particularly in Europe, this followed the strategy of simply buying whatever is needed for domestic high-tech production on the global market. This worked fine at least until 2008, when China introduced export restrictions on rare earth elements (REE). Suddenly, Europe and its legislative bodies had to 'wake up' realizing the import dependency and the resulting danger for its production of modern technologies including wind turbines and hybrid cars [34]. While, on a policy level, this resulted in first actions such as 'The raw material initiative' [35] in 2008, this paradigm change has not yet fully reached our overall society. The common understanding of primary care increasingly includes tangible goods without scrutinizing their origin [36].

Western society must be aware that the demand for primary raw materials, while reducing supply risk in the mid-term and long-term, might only be met by independent primary production and/or the supply of secondary raw materials through recovery and recycling and, thus, moving toward a circular economy using its innovation capacity.

\section{Research Method}

Our work is based on a comprehensive literature study in which, for the most part, we focused on peer-reviewed articles. These are supplemented by a few selected books, book chapters, and three oral conference presentations where no conference proceedings were available [3,26,37,38]. As illustrated in the previous section on CE, the concept is often driven by practice. Therefore, sources from the Mac Arthur Foundation are used, which are comparable to official documents by various legislative entities of the European Union. Particularly, regarding the outlined case studies we base our research on, a strong transdisciplinarity-oriented approach where expert knowledge from practice is linked with state-of-the-art scientific knowledge to foster a mutual learning process. This took place during the case selection as well as within the selection of appropriate (company) sources. From a scientific perspective, the conference proceedings from SYMPHOS represent a useful source for issues on innovation and 
technology in the phosphate industry (see Procedia Engineering Volumes: 46, pages 1-298, 2012; 83, pages 1-484, 2014, 138, pages 1-498, 2016).

The literature reveals that the relationship between the circular economy and mining has only been vaguely explored and mostly explored within quite narrow perspectives such as waste utilization [39-41] particularly in the context of landfill and/or urban mining [42,43], iron mining and steel production [44,45], coal mining [46], and indium utilization [47]. P-related issues mainly address recovery from sewage in the present cases referred to as sewer or liquid mining [48,49].

Within our research, we aim to take a broader scope based on the case of phosphates. Therefore, we intend to:

i. Connect the concept of a circular economy to mineral extraction and phosphate rock mining in particular.

ii. Examine the idea of reducing losses by increasing resource efficiency and closing the loops along the value chain particularly in mining and beneficiation.

iii. Provide innovative best-practice examples in PR mining that foster sustainable development and resilient mineral resource strategies.

The bottom line is that every P particle that ends up in the final product (i.e., food or animal feed) instead of being lost along the supply chain contributes to the ambitious goal of a Circular Economy (CE) for phosphorus and increases resource efficiency. While extraction and beneficiation phases are not parts of the circle per se, both can contribute to a greater phosphorus net gain from primary production remaining in circulation.

\section{Phosphate Rock Mining-Obstacles and Opportunities on the Journey Toward a P Circular Economy}

Phosphate rock, which is the almost-exclusive primary source for $\mathrm{P}$, represents a bulk commodity. In terms of overall production volumes of non-energy minerals, it ranks fifth with 255 million metric tons (PR-M) for 2016, which is following closely behind gypsum, salt, and bauxite but is farther from the iron ore [25]. Hence, given the magnitude of processed volumes, considerable small adaptions to the value chain may account for great improvements. In their most recent work, Geissler et al. [25] introduced the Phosphate Rock Mining-Innovation Nexus (see Figure 2) as a means to frame and structure the most prominent issues related to phosphate rock mining. The latter consist of (i) improving $\mathrm{P}_{2} \mathrm{O}_{5}$ recovery during extraction and beneficiation, (ii) utilizing waste in the in the mining and processing phase, and (iii) recovering by-products, which are all considered within the boundaries of sustainable development and driven by sustainable innovation of various dimensions and degrees.

Subsequently, we build and extend on the nexus and consider the mining phase from three major perspectives: the geological perspective (i.e., the geosphere), the technological and process perspective (i.e., the technosphere), and the economic perspective (the value sphere). Since all three are part of the supply chain, geological settings are inseparable from technological developments and economic considerations. This coupled-systems perspective should shift the discussion away from being predominantly technology-focused toward the interaction between human systems and the environment.

Nevertheless, we discuss the three dimensions separately and highlight the main issues calling for innovation in order to foster a P circular economy and, eventually, sustainable management.

\subsection{The Geological Perspective (the Geosphere)}

The composition of ores defines whether their beneficiation and processing are commercially viable. Steiner et al. [6] identified a set of parameters affecting the character of the deposit such as ore grades (i.e., $\mathrm{P}_{2} \mathrm{O}_{5}$ content), ore depth (including overburden depth), ore-layer thickness, additional ore-body variables (e.g., hardness, grain size, and mineralogy), and chemical impurities. 
Regarding the latter, cadmium $(\mathrm{Cd})$ and uranium $(\mathrm{U})$ in particular pose risks to the environment (e.g., soil contamination) and to human and animal health [50]. While igneous ores in South Africa, Brazil, and Russia contain less than $2 \mathrm{mg} \mathrm{Cd} / \mathrm{kg} \mathrm{P}_{2} \mathrm{O}_{5}$, sedimentary ores contain considerably more. Ores from Morocco and Tunisia range up to 51 and $56 \mathrm{mg} \mathrm{Cd} / \mathrm{kg} \mathrm{P}_{2} \mathrm{O}_{5}$ respectively and Senegal exceeds this by a factor of 2 . In contrast, the same type of ore from Jordan averages $5-6 \mathrm{mg} \mathrm{Cd} / \mathrm{kg}$ $\mathrm{P}_{2} \mathrm{O}_{5}[37,51]$. Regarding $\mathrm{U}$ in phosphorus fertilizers, studies indicate that its content increases with increasing $\mathrm{P}_{2} \mathrm{O}_{5}$ content of the product by reaching levels up to $362 \mathrm{mg} \mathrm{U} / \mathrm{kg}$ in fertilizers derived from phosphate rock of sedimentary origin. Enrichment takes place during the processing and production of phosphoric acid [52]. The content of $U$ in phosphate rock is highly dependent on the type and origin of the rock. Studies show that U content lies between a reasonably low 23-31 mg U/ $\mathrm{kg}$ in Chinese rock and 182-220 mg U/ kg in Brazilian rock. For a detailed breakdown of the 10 largest phosphate rock producing countries, see Reference [53].

Referring to the current legal situation vis-à-vis contamination, the European Commission issued a press release in early 2016 stating that a new regulation on cadmium loads in all types of fertilizer (organic and non-organic) will go into effect. It will reduce cadmium from $60 \mathrm{mg} \mathrm{Cd} / \mathrm{kg} \mathrm{P}_{2} \mathrm{O}_{5}$ to $40 \mathrm{mg}$ $\mathrm{Cd} / \mathrm{kg} \mathrm{P} \mathrm{O}_{5}$ within three years and further reduce it to $20 \mathrm{mg} \mathrm{Cd} / \mathrm{kg} \mathrm{P}_{2} \mathrm{O}_{5}$ after 12 years. The goal is not only to reduce health and environmental risks as well as reduce waste and energy consumption but also to foster equitable commercial opportunities for organic-based fertilizers and, thereby, innovative companies [54]. However, the regulation is currently being heavily contested by many industrial stakeholders and the proposed Cd limits are not accepted by a number of countries $[55,56]$.

Innovations may not be limited to on-shore development. Currently, $50 \mathrm{Gt}$ of the $68 \mathrm{Gt}$ of known and classified global phosphate rock reserves are located in Morocco and the disputed territory of the Western Sahara [57]. Given the growing demand as well as the import dependency for most countries, new reserves and producing countries could ease future supply risk. Moreover, the untapped mineral potential on the seabed could be a (controversial) future source of raw materials (see Case 3).

\subsection{The Technological and Process Perspective (Technosphere)}

The technosphere is defined as "the artificial world created by man such as surface and subsurface constructions, machines, consumer products, or waste dumps" [58]. We consider the technosphere to be the overall supply chain based on available and applied technology by mining, processing, and production enterprises.

Equipment and methods for phosphate rock mining are usually very similar to those for coal mining. Phosphates are mined either above the surface (i.e., open-pit, open-cast mining), where mining takes many forms from manual to highly mechanized operations, or below the surface (i.e., underground mining), where the conventional room and pillar methods can be found, as well as continuous mining. Regarding volume, surface mining is the most utilized method by far. CRU International [59] reports a ratio of 3 to 1 for open-pit mining phosphate rock capacities while, outside of China, only $5 \%$ of the global capacity is mined underground (Russia, Kazakhstan, Mexico, and Egypt). High-volume open-pit applications are mostly less costly and generally the preferred method given suitable deposit geometry and other parameters [60].

Borehole mining (i.e., underground hydraulic mining, slurry mining, or jet boring), which is a nearly forgotten innovation that originated in the past, might once again become of interest in the future. This form of mining uses water-jet cutting systems and downhole slurry pumps to extract subsurface minerals through a single borehole drilled from and up to the surface for further treatment [61]. During the 1970s and '80s, multiple studies were conducted to evaluate the economic feasibility of mining deep phosphate deposits. Under certain conditions, mostly involving large overburden thicknesses (>150 ft), borehole mining was found to be economical [62]. This study also characterized the technology as environmentally more desirable due to its smaller surface impacts. Economic disadvantages arise mostly from not having economics of scale. Using additional equipment might compensate for this shortcoming. Alternatively, advances in technology such as horizontal 
drilling might allow greater tonnage to be accessed from each borehole. Marvasti [63] showed similar favorable results, which indicates that borehole-mining technology might be more cost-efficient than strip mining under certain conditions.

With regard to beneficiation (i.e., primary recovery, which turns the in situ ore into marketable concentrate), the availability of water is of great importance and may even exclude deposits from production. The most common steps in beneficiation include a screening process (washing ore or dry-screening if water access is limited or restricted), a sizing or separation step (e.g., grinding and screening, which is also referred to as comminution and classification steps), and further ore-dependent steps like de-sliming (for most sedimentary ores) and/or flotation. Even though ore characteristics are vastly different, these steps remain more or less similar for sedimentary as well as igneous ores. Where seawater or brackish water is used for washing and size classification (or even flotation in some cases), a final freshwater rinse is required to remove chloride from the final concentrate $[6,60]$. Although igneous in situ ore is generally lower in grade (i.e., lower $\mathrm{P}_{2} \mathrm{O}_{5}$ content) than sedimentary ore, processing leads to higher grades in the final concentrate (Table 1).

Table 1. Average grades of in situ ore (PR-Ore) and marketable concentrate (PR-M) in $\% \mathrm{P}_{2} \mathrm{O}_{5}$ (columns 3 to $6=$ mainly sedimentary ore, columns 7 to $9=$ mainly igneous ore) based on [6].

\begin{tabular}{ccccccccc}
\hline & World & US & China & Morocco & Jordan & Russia & South Africa & Brazil \\
\hline PR-Ore & $17.5 \%$ & $11.8 \%$ & $21.6 \%$ & $26.4 \%$ & $25.5 \%$ & $10.1 \%$ & $7.0 \%$ & $11.1 \%$ \\
PR-M & $30.1 \%$ & $29.2 \%$ & $28.1 \%$ & $31.5 \%$ & $29.7 \%$ & $38.7 \%$ & $37.3 \%$ & $35.4 \%$ \\
\hline
\end{tabular}

Current research targets both sub-processes of mining, extraction, and beneficiation. For example, Asri and Daafi [64] proposed using cast blasting in the extraction phase to reduce stripping costs by up to $8 \%$. In beneficiation, we find various attempts to increase the grade of the marketable ore (without increasing the cut-off grade) and to raise recovery levels for sedimentary as well as igneous ores. The latter was addressed by Albuquerque et al. [65] who tested a flotation reagent scheme consisting of cornstarch and coconut oil. They found that both were effective for the separation of apatite from contaminants (calcites and silicates). Separation was targeted by Bittner et al. [66], who proposed the use of a processing system based on triboelectric charging and electrostatic separation especially for fine material in a completely dry process.

Other researchers have worked specifically on the utilization of waste or currently unused by-products in the processing chain such as furnace slag, phosphogypsum (PG) tailings, or process water. Gallala et al. [67] conducted laboratory experiments to turn coarse rejects (i.e., waste from the first process steps in beneficiation) into a marketable concentrate of close to $29 \% \mathrm{P}_{2} \mathrm{O}_{5}$. Regarding tailings as a beneficiation by-product, research suggests that their geotechnical properties make them excellent alternatives to conventional borrow pits. Rocks, as part of the overburden of sedimentary basins, might be used as construction material, marble mosaic floors, mortars, concrete, and more [68].

Generally, improvements or necessary adaptations are made either voluntarily because of cost structure, available technology, or other aspects of strategic mine management or are made by involuntary drivers such as ore characteristics or market developments.

\subsection{The Economic Perspective (Valuesphere)}

The Austrian World Mining Data reported a total mining production of 16.9 billion metric tons (excluding construction materials and bauxite) for 2016 [32]. In economic terms, the 40 top mining companies generated a total revenue of 496 billion USD for 2016 and 600 billion USD in 2017 [69] with a market cap of 871 billion USD for 2016 [70]. These figures underline that mineral resources represent natural assets of remarkable economic value to stakeholders and to shareholders of various forms in particular. Nevertheless, history shows that the sole availability of natural mineral resources does not automatically guarantee success in national economic development (e.g., in the form of GDP per capita). The term "Resource Curse" was coined in 1993 by Richard Auty, who used it to 
describe negative impacts of resource richness on factors like corruption and violence [71]. Another term commonly used in this context is "Dutch Disease". It refers to unpleasant side effects of upward price swings (i.e., booms) of mineral commodities for exporting countries since national economies may overlook potential temporality in their focus on certain minerals [72].

In the case of PR, one country, in particular, immediately comes to mind-Morocco. Currently, the country is holding approximately three-quarters of the global PR reserves and is the largest exporting country of phosphate rock through the state-owned and controlled OCP S.A. [73]. Below, Table 2 shows the economic contributions of PR and further downstream products of OCP for Morocco, averaging a share of 5.6\% between the years 2007 and 2016 .

Table 2. OCP's contribution to the Moroccan GDP (OCP turnover based on annual company reports, GDP based on tradingeconomics.com, and exchange rates based on oanda.com).

\begin{tabular}{cccccc}
\hline \multirow{2}{*}{ Year } & OCP Turnover & Morocco GDP & Exchange & Morocco GDP & OCP/Morocco \\
\cline { 2 - 5 } & Bill MAD & Bill USD & MAD/USD & Bill MAD & \% \\
\hline 2007 & 27.5 & 79.0 & 8.2 & 647.5 & 4.3 \\
2008 & 60.0 & 92.5 & 7.7 & 715.9 & 8.4 \\
2009 & 25.0 & 92.9 & 8.1 & 751.3 & 3.3 \\
2010 & 43.0 & 93.2 & 8.4 & 785.0 & 5.5 \\
2011 & 56.4 & 101.4 & 8.1 & 820.5 & 6.9 \\
2012 & 59.4 & 98.3 & 8.6 & 848.5 & 7.0 \\
2013 & 39.0 & 106.8 & 8.4 & 898.3 & 4.3 \\
2014 & 41.4 & 109.9 & 8.4 & 924.0 & 4.5 \\
2015 & 47.7 & 100.6 & 9.8 & 981.0 & 4.9 \\
2016 & 42.5 & 103.6 & 9.6 & 994.7 & 4.3 \\
\hline
\end{tabular}

The definition of loss incorporates "the act of losing possession" [7]. We face losses at every stage along the phosphorus supply chain. However, not every loss qualifies for the term, according to the definition above. This raises the question of where we should start to minimize losses and, in turn, increase efficiency in order to support sustainable mineral-resource management and foster a circular economy.

On a company level, especially for extraction, the determination of site-specific (or even phosphate rock bed-specific) cut-off grades represents the distinguishing parameter in relation to what needs to be considered a loss. The current phosphate rock price level is a major driver influencing the cut-off grade, which basically defines the boundary below which the PR-Ore becomes uneconomical. Time, therefore, is another influencing parameter. Untouched PR-Ore below the defined cut-off grade should not be considered a loss but rather a resource for future generations, when available technology and/or higher price levels may enable economical extraction and processing. However, this requires cautious logistical steps in the present. Once low-grade material is used in reclamation processes together with zero-grade waste, valuable resources are potentially lost forever. In the mid-term and short-term, innovations must aim to avoid "real losses" (touched PR-Ore above cut-off grade) in extraction as well as in beneficiation. Steiner et al. [6] illustrated this with Bed 3 from OCP's Khouribga Mine where the low-grade Bed 3 was mined and stockpiled until it could be upgraded economically, which is a best-practice example of maximizing resource potential as well as innovatively managing reserves.

Further mine-specific considerations evolve around the mineral characteristics and the recovery potential of additional minerals within the compound. By definition, the main difference between by-products and co-products is their contribution to the economic viability of a mine. While co-products are generally required in order to enable viability, by-products are associated with the mine's main product. In addition to being essential for plant growth, the phosphate rock is a well-known source of other important and valuable mineral raw materials especially uranium $(U)$ and potentially rare earth elements (REE). Phosphate rock accounts for more than $80 \%$ of the globally known unconventional uranium resources [74]. More than $15 \%$ of the global demand (for peaceful purposes) could be met as 
the by-product of phosphate-based fertilizer production [75]. With regard for sustainable development, there is no question that we should recover $\mathrm{U}$ from $\mathrm{P}$ fertilizer production rather than contaminating our farmland. However, economic viability remains in question and is the limiting factor for recovery. Since 2007, spot market prices for $\mathrm{U}_{3} \mathrm{O}_{8}$ have been in the range of USD 18 to 40 per pound (USD 39.7-88.2 per kg), while current recovery costs of solvent extraction (proven at industrial scale) remain significantly higher at USD 44 to 61 per pound (USD 97-134.5 per kg). A remedy may be found in improved ion-exchange technology where pilot plants promise higher recovery rates at lower costs [76]. Regarding the REE supply through phosphate rock, a similar picture can be found. Zhang [74] estimated that 170 million metric tons of phosphate rock production (current production figures are even higher) could yield a total of nearly 100,000 tons of REE. He showed in his mass balance analysis that approximately 30,000 tons of REE are discarded annually in Florida alone. This exceeds the total annual US REE demand by a factor of two. In the case of Russia, the integrated producer PhosAgro developed REE recovery from ore in the Khibiny deposit where $41 \%$ of Russia's REE is located, according to its 2016 annual report. Furthermore, the Russian Acron Group has produced about 200 tons of Cerium, Lanthanium, and Neodymium-oxides and REE concentrates from ore from the Oleniy Ruchey mine, according to official company reports in 2016.

\subsection{Striving Toward a Circular Economy of $P$}

From a system's perspective, an economy is typically confined by geographical (e.g., regional, national, or supra-national) system boundaries. This results in systems such as the European economy or the Austrian economy and also holds true in the context of a circular economy. Nevertheless, as briefly addressed earlier, it might make sense, depending on the context, to consider alternative system boundaries to confine an economy. Hence, we propose the concept of a phosphorus circular economy based on the system boundaries of the P supply chain. Our concept is considered mostly on, but not limited to, a global level. Thus, additional geographic boundaries might be applied.

Although a CE is viewed (within the practitioner literature) as an "economy that provides multiple value-creation mechanisms, which are decoupled from the consumption of finite resources" [77]. We don't see a contradiction. Following circular principles, all measures that tend to close loops along the supply chain will have a positive effect as the valuable resource enters the intended use circle instead of being lost somewhere along the way.

The mining of PR deposits has been the dominant way to feed the anthropogenic phosphorus-use cycle for more than a century. However, mining should not be seen as the lone feeding mechanism for primary phosphorus resources. Rather, it is simply the currently dominant one. While the primary source of phosphorus historically was human and animal bones as well as bird excreta (i.e., guano deposits) [78], future sources might involve economically feasible mass recovery from sewage sludge or currently unimaginable or unknown sources. In addition, even though it is true that, in an ideal circular P economy, mining (or feeding of the cycle) would not be necessary at all, there is still (in the best-case scenario) a long way to go [79] due to a constantly growing demand, factually impossible loss-free recovery rates, or time delays through the stock building in soils.

Most $\mathrm{P}$ atoms we lose from mining today (e.g., overburden or below cut-off grade material) and within beneficiation (fine tailings) plants might never reach the agricultural phosphorus-use cycle. These considerations make today's PR mining essential for the journey toward a circular phosphorus economy. Figure 3 below is based on the idea of a Sankey diagram illustrating P flows and losses along the supply chain. However, the size of the arrows does not reflect amounts. The arrows indicate flows (black), (potential) losses (red), and the potential for recovery through the closure of loops (green) besides end-of-life recycling (black).

While the present paper considers the overall issue from a narrower and more functional perspective, Scholz and Wellmer [38] most recently presented their concept of a "prudent evolutionary circular economy" by introducing "circular economics" as a meaningful approach for fundamental system changes. 


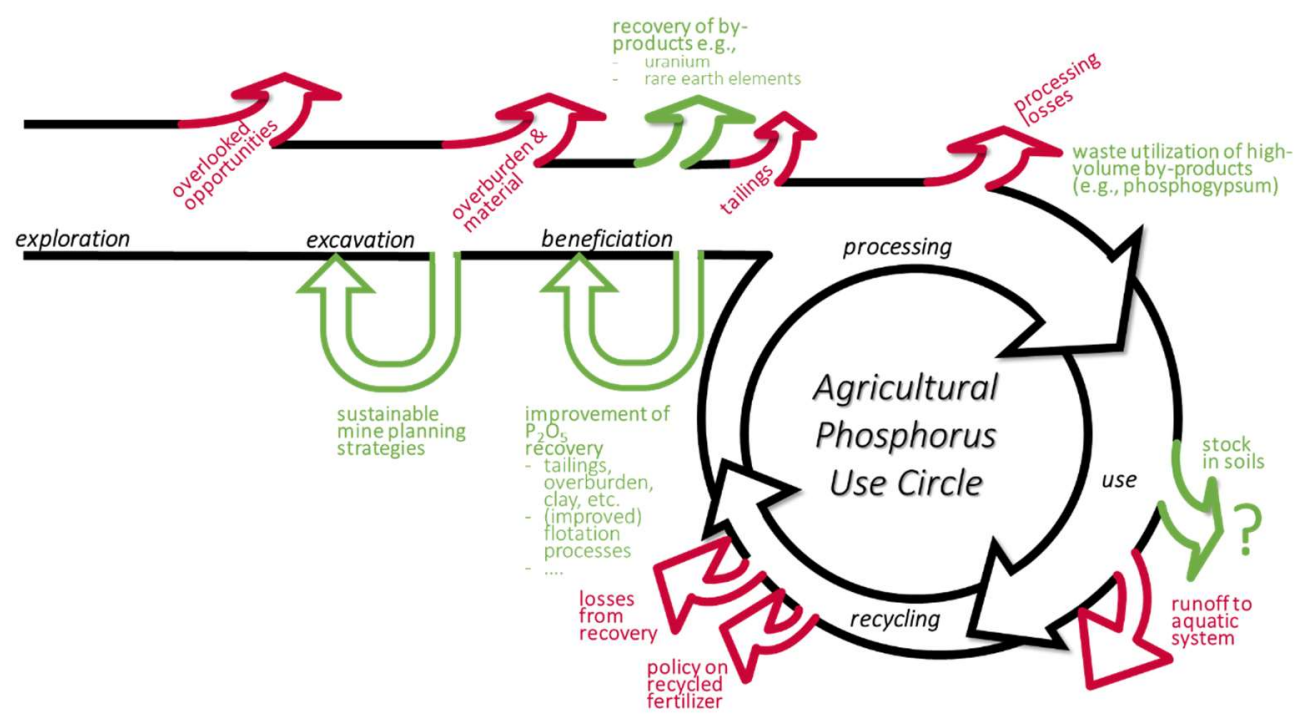

Figure 3. Circular principles for moving toward a circular phosphorus economy.

\section{Cases}

\subsection{Case 1: Slurry Pipeline of OCP S.A.}

Although it's been in place since around 1967, in recent years, pipeline transportation of mineral slurries has become a viable alternative to traditional rail or road transport especially in terrains where these are unsuitable. Generally, this method of continuous transportation has many advantages over discrete traditional alternatives. Pipelines reduce environmental impact in the form of noise, pollution, and emissions along the route and reduce losses while offering advantages for the variable-cost structure compared to fleets with labor-intensive loading and off-loading. Depending on the terrain, savings in investment costs especially for remote mines might even be realized since pipelines are less expensive compared to building bridges or even tunnels [80].

The Jorf Lasfar phosphate-slurry pipeline (see Figure 4) of Moroccan OCP S.A. was commissioned in April 2014 as the world's largest phosphate-slurry pipeline. The main pipeline connects the head station located at the Khouribga Mine to the $187 \mathrm{~km}$ remote terminal station at the Jorf Lasfar hub on the coast near El Jadida, where OCP has most of its downstream processing plants. Secondary pipelines with an overall length of $48 \mathrm{~km}$ are used to receive phosphate ore at the head station from the El Halassa, MEA, and Daoui wash plants. Given the varying grade and quality of the ores from the different plants, the slurry is stored in separate tanks at Khouribga and then pumped in batches to El Jadida. The arriving slurry is directed into different storage tanks feeding further downstream processes in the Jorf Lasfar complex [81]. Phosphate rock destined for export is dried at Jorf Lasfar.

With regard to further technical specifications, the pipeline is designed with a diameter of $0.9 \mathrm{~m}$ for a transport capacity of 38 million tons per year two meters below the surface. It surpasses the previous conventional capacity of 18 million tons by far. The phosphate rock is enriched by washing and flotation with a phosphate pulp mixing ratio of $60 \%$ phosphate and $40 \%$ water by preparing the slurry for natural-gravity hydro-transport. The overall investment costs of 4.5 billion Dirhams (approx. USD 476 million, as of August 2017) are creating massive annual savings of an estimated $90 \%$ in logistical costs and 3 million cubic meters of water as well as 930,000 tons of $\mathrm{CO}_{2}$ [82]. Based on official financial reporting, in 2014, the pipeline transported 2.7 million tons, which increased to 6.5 million in 2015. In 2016, the volume equaled a savings of MAD 800 million or approximately USD 12 per ton. As the volume increases, average unit savings will drop since the figure of USD 12 includes savings on both transport and drying whereas we estimate USD 7-8 per ton for transport and USD 4-5 per ton for drying. Thus far, all the material transported has been for local use in downstream processes 
and, therefore, not dried. Phosphate rock for export will require drying at Jorf Lasfar and will, thereby, reduce the overall per-unit savings.

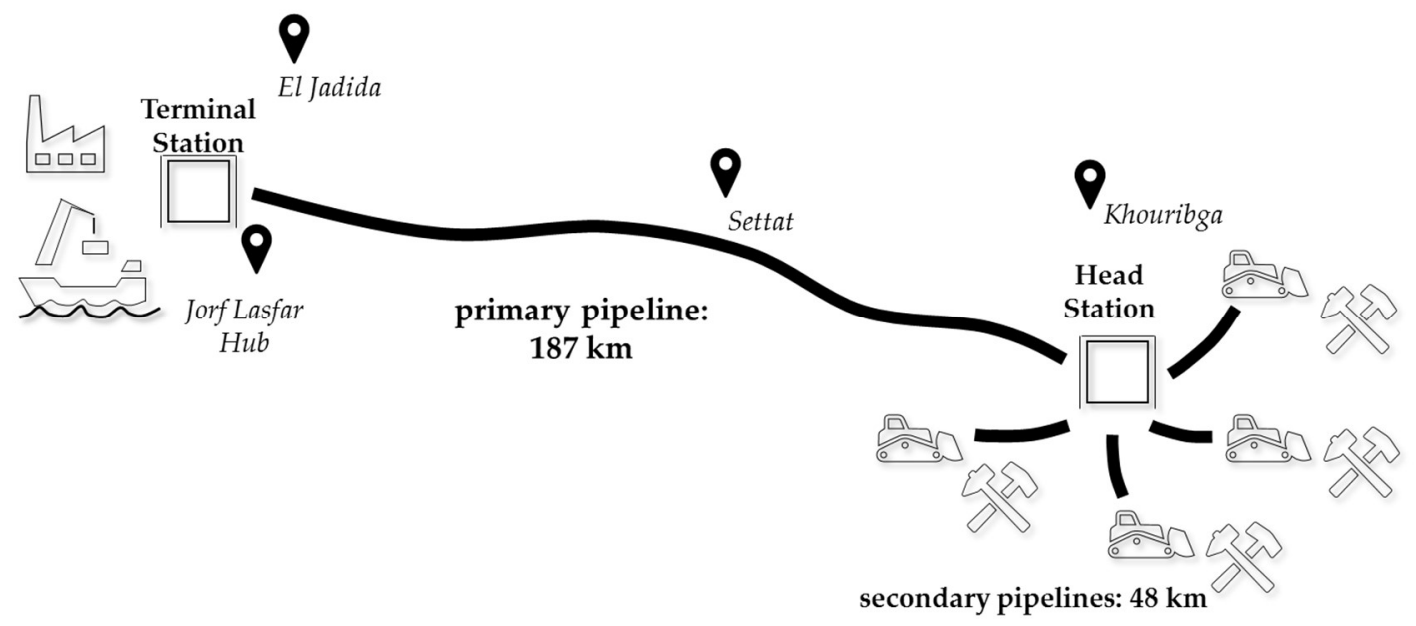

Figure 4. Khouribga-Jorf Lasfar Pipeline (based on [82]).

\subsection{Case 2: Improved Hard Process (IHP)}

For economic reasons, phosphoric acid (PA) is almost exclusively produced through the Wet Acid Process (WAP). Exceptions for the more energy-intensive electric-furnace process (EFP, a thermal process) can, for the most part, be found only in the production of elementary phosphorus (e.g., in China and Kazakhstan). Besides being less energy-consuming and, therefore, economically preferable, the WAP comes with several disadvantages. The main by-product of the process is phosphogypsum (PG). For every $\mathrm{P}_{2} \mathrm{O}_{5}$ ton of PA, approximately five tons of PG are produced. Currently, PG is considered a high-volume waste that is either stacked on land or pumped into the sea, but neither of the two solutions can be considered environmentally-friendly. The requirements for phosphate-rock concentrate as the main input to the process present additional concerns. The WAP generally requires highly beneficiated phosphate rock ore (i.e., high-grade concentrate) as well as a relatively low level of impurities such as $\mathrm{MgO}, \mathrm{Cl}, \mathrm{Al}_{2} \mathrm{O}_{3}$, and $\mathrm{Fe}_{2} \mathrm{O}_{3}$ for processing reasons and heavy metals like $\mathrm{Cd}$ since, depending on the process used, more or less of this remains in the final product.

Generally, deposit grades are decreasing and impurities are increasing, which requires more intensive (costs and resources) beneficiation. Furthermore, national and supra-national policy-makers are tightening regulations on impurities in fertilizers, which is already shown. Both issues might be addressed in the future through the Improved Hard Process.

The original hard process developed in the late 1970s and early 1980s was based on the kiln-based process from the 1950s. Although pilot plants were able to validate the technology and produce high-quality PA, the cost efficiency was too low to compete with the established WAP. In the early 2000s, significant discoveries were made, which led to the IHP and increased the throughput capacity by a factor of five [83].

Lower-grade phosphate-rock concentrate $\left(>15 \% \mathrm{P}_{2} \mathrm{O}_{5}\right)$, petroleum coke, and silica sand are fed to a dryer in order to remove moisture. The output from the dryer is screened and ground and then the balling equipment is used to produce 3/8-inch-diameter (approximately $9.5 \mathrm{~mm}$ ) balls. The induration rotary kiln is used to preheat the material with the beneficial side effect of eliminating most of the heavy-metal impurities. Within the main kiln (rotary kiln, ported kiln), phosphorus is reduced from the balls and together with oxygen compounded to $\mathrm{P}_{4} \mathrm{O}_{10}$ gas. Using a standard acid hydrator, the phosphoric gas is cooled and absorbed in water, which produces a $70 \% \mathrm{P}_{2} \mathrm{O}_{5} \mathrm{PA}$. The remaining material (mostly hard calcium silicate) from the main kiln is cooled and sold for use as construction aggregate [84]. Subsequently, Figure 5 shows a simplified flowchart of the process. 


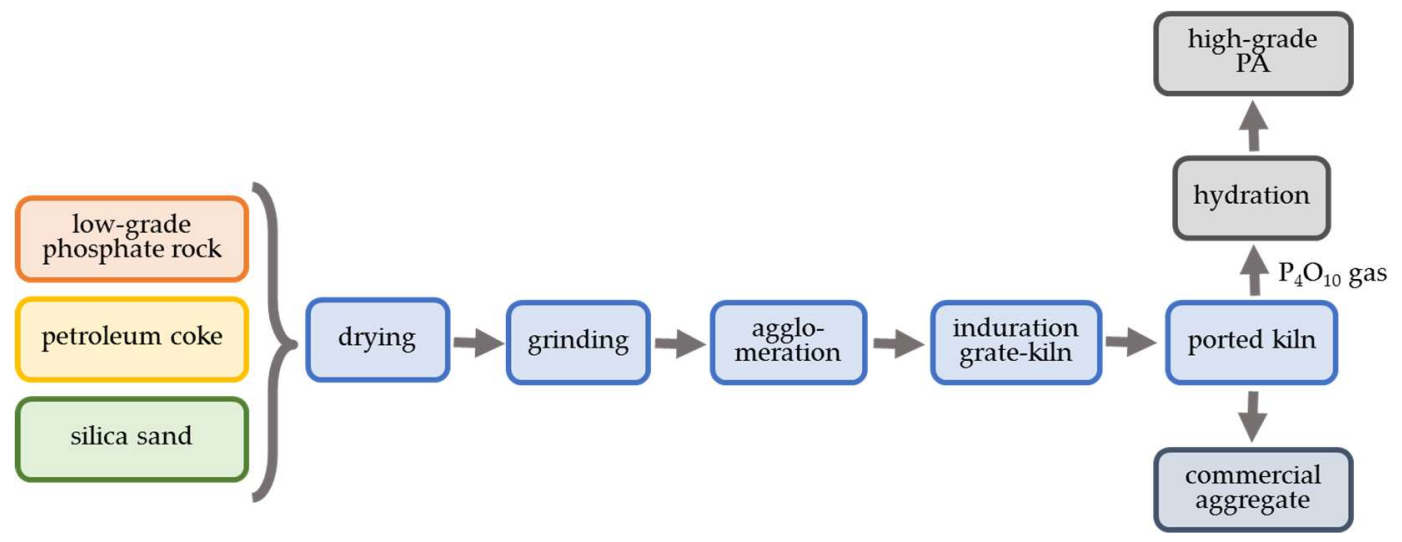

Figure 5. IHP flowchart with pretreatment kiln (based on [84]).

Besides the possible use of low-grade ore, the demo plant shows high efficiency and effectiveness in the removal of impurities. Additionally, $60 \%$ of aluminum, $62 \%$ of arsenic, $91 \%$ of cadmium, $97 \%$ of lead, and $95 \%$ of chlorides have been proven to be eliminated. The avoidance of phosphogypsum production and the higher quality of PA are referred to as further advantages in this technology [84]. The IHP is still in a development phase. A small-scale commercial unit should be completed by the end of 2018. In addition to tests on various rock-ore types, research is also focusing on energy optimization since, currently, $50 \%$ of the overall energy is used in the ball mill [85].

\subsection{Case 3: Seabed Mining - Namibia and New Zealand}

The potential for mining minerals from the seabed presents an interesting case study of conflicting perspectives, particularly as seabed mining is still at a relatively early stage of development and, as yet, untested in most cases with regard to economic and technical feasibility in contrast of potential ecological threats. Large-scale mining projects are just starting or scheduled to start such as diamond mining off the coast of Namibia or sulfide mining at the Manus Basin off eastern Papua New Guinea [86].

In the PR sector, there are two main proposed projects currently being pursued by Chatham Rock Phosphate Ltd. on Chatham Rise near NZ and by Namibian Marine Phosphate (Pty) Ltd. on the Saldanha Bay offshore deposit. The latter comprises the marine dredging project Sandpiper that will mine the PR sediment deposits about $60 \mathrm{~km}$ off the coast of Namibia in $180 \mathrm{~m}$ to $300 \mathrm{~m}$ water depth [87]. However, the project was suspended in 2013 due to environmental concerns [88] and the most-recent announcements indicate that the project may finally be terminated since the original environmental clearance certificate (granted by the Ministry of Environment and Tourism) was withdrawn through appeal [89-92].

Generally, the mining of minerals from the seabed brings in four major perspectives: economic, ecological, and social. All need to be addressed in assessing projects.

From an economic perspective, companies and governments want to exploit mineral resources similar to what they do on land. Companies gain profits and governments gain royalties, taxes, and employment. In the case of Namibia, it was the government that delineated the resource initially in the 1970s. Companies subsequently sought permission to evaluate the mineral potential in greater detail with a more or less implicit assumption that, if the project was found to be economical, extraction would ensue. However, environmental groups as well as competing interest groups (largely fishing industries) have, thus far, campaigned against mining by citing a lack of scientific knowledge that is needed to assess the impact of mining on the ecosystems involved. Under the United Nations Convention on the Law of the Sea (UNCLOS), the International Seabed Authority (ISA) is "charged with ensuring effective protection of the marine environment as part of its responsibilities for managing mining in seabed areas beyond national jurisdictions on the behalf of humankind." A comprehensive 
review of the potential environmental impacts and state of knowledge is outside the scope of this paper but can be found in Levin et al. [92].

\subsection{Case 4: Yara's Paste Thickener}

Flotation residues are typically stored in tailing ponds. They leave the post-flotation concentrators as a slurry with $40 \%$ to $50 \%$ solids. Usually, the slurry is too liquid to be stockpiled and the ponds need to be confined by dams. Particularly during recent years, this practice has come under public scrutiny due to broken dams that have devastated large areas (e.g., the Bento Rodrigues dam disaster in November 2015 in Minas Gerais, Brazil where, following a dam failure, flooding iron-ore tailings destroyed the village killing 17 people and leaving 375 families homeless [93]). However, criticism extends not only to the inherent risk of disasters but also to the excessive waste of water that has become increasingly critical in areas with scarce water resources.

Paste thickeners may be a viable solution to phosphate mining operations such as the plant commissioned by Yara in its Siilinjärvi phosphate mine (Finland) in February 2017. The mine produces about one $\mathrm{Mt} /$ year of phosphate-rock concentrate containing $36 \% \mathrm{P}_{2} \mathrm{O}_{5}$. In Finland, the problem was that the existing tailing pond came close to its end-of-life capacity. The options were to (i) build a new tailings pond, (ii) raise the dam of the existing tailings pond, or (iii) invest in new technology that would allow the use of the existing storage facility for years to come. Not wanting to increase the environmental footprint of its mining and beneficiation operations, Yara opted for technology investment.

The problem had been on Yara's agenda since the 1980s, but, at that time, technology to deal with the problem was not yet available. The challenge of thickening the flotation tailings of the Yara mine involved the unique properties of the tailings material: "The material is coarse but also contains a high proportion of mica and a fine fraction, which is difficult to aggregate with the coarse particles using flocculation. The material settles and consolidates rapidly to form a highly structured material at a high density and yield stress. This creates problems in mixing tanks, thickeners, pumps, and pipelines and causes blockages if the material segregates and consolidates [94]."

In 2010, the project started with testing work and the construction of a $14 \mathrm{~m}$-high pilot plant where tests were performed until 2014. In 2015, Yara awarded a 40 M€ EPC contract to Outotec to engineer, procure the components, and commission the final paste-thickening plant consisting of two 30 m-high thickeners, slurry tank, flocculant-dosing unit, a pumping and automation system, and necessary ancillary equipment (as shown by the simplified flowsheet in Figure 6).

The new paste thickener improves the dry-matter content of the tailings slurry from an initial $45 \%-48 \%$ to $68 \%-70 \%$ and reduces the slurry flow from an initial $1720 \mathrm{~m}^{3} / \mathrm{h}$ to just $940 \mathrm{~m}^{3} / \mathrm{h}$. The overflow water, $810 \mathrm{~m}^{3} / \mathrm{h}$, is recycled to a water pond and reused as process water. The thickened tailings allow for a slope angle of 4 degrees, which is dense enough for forming piles.

The paste thickener improves safety and conserves water in the Siilinjärvi phosphate plant, which is almost half of the process water coming from the recycled flotation. In addition, it allows Yara to use the existing tailings pond until the expected end of life of the mine in 2035. Even if the two cases are not directly comparable, relating an investment of $40 \mathrm{M} €$ to Samarco's (the operator of the Brazilian iron ore mine) own estimation of about 3.4 bn USD cost of the environmental damage from impacts to land, water resources, and biodiversity resulting from a dam failure, the choice should be clear. However, since risks are not typically included in balance sheets and company ratings, managers frequently prefer the risk to the safety option (case is based on References [94-96]). 


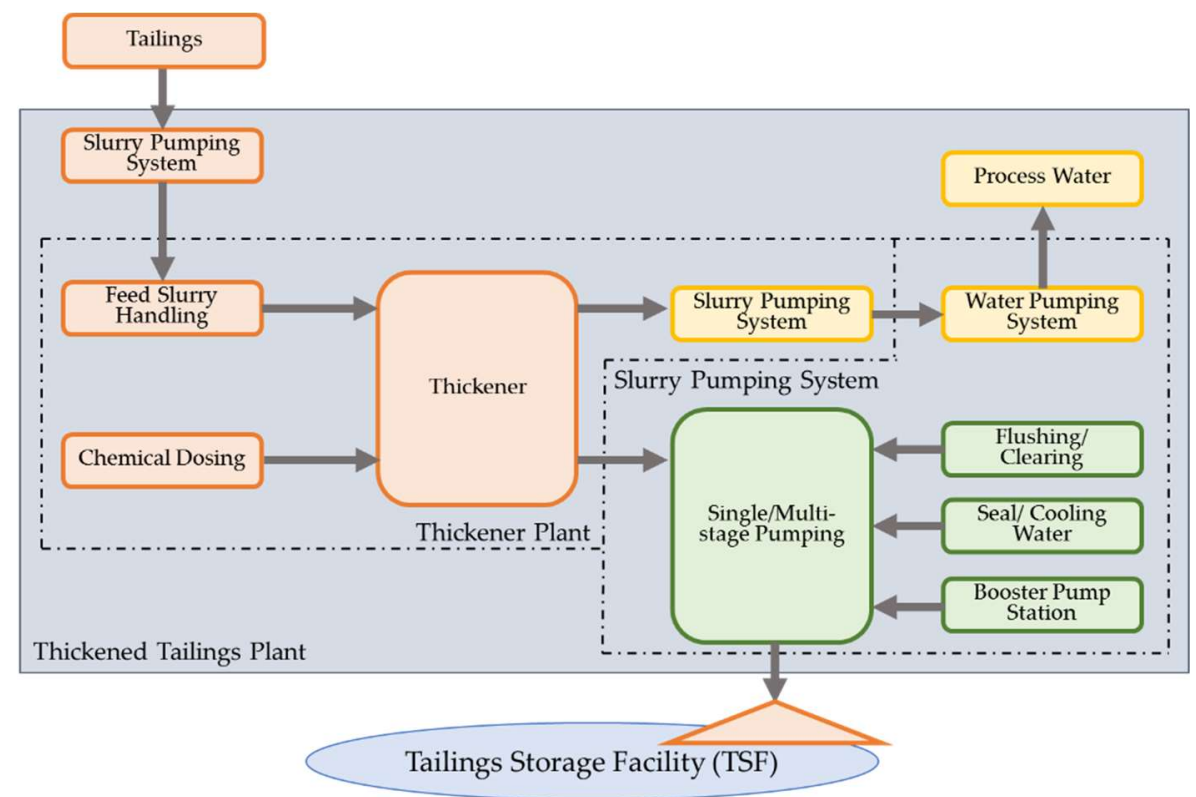

Figure 6. Simplified flowsheet of flotation tailings thickener (based on [95]).

\section{Discussion and Conclusion}

According to current estimates from the UN, by 2050, Earth will host more than nine billion people. Although resource consumption depends greatly on available income, all humans consume resources to some degree. Even if we were not facing (economic) scarcity of a particular resource, a transition toward more sustainable production and consumption is inevitable. Almost 30 years after the emergence of the Brundtland Report, 193 nations adopted the 17 Sustainable Development Goals (SDGs) of "Transforming our world: the 2030 Agenda for Sustainable Development" through the UN General Assembly in 2015. A year later, COP 21 (Paris Agreement), which was ratified by 195 countries, came into force. It should be obvious since then that producing more with less is imperative if we are to accommodate the global demand within our planetary boundaries [78]. As for phosphorus and its unique characteristics of being essential, non-substitutable and finite in the form of concentrated PR deposits, this must be valid and of particular interest for all directly involved stakeholders and for the whole society.

\subsection{Circular Economy, Sustainability, and Resource Efficiency Go Hand-in-Hand}

From a simplified mathematical perspective, a constant demand (a sufficient and effective output level) at decreasing primary inputs (e.g., such as those based on mining) can be attained if current losses are avoided and if efficiency (e.g., of a supply chain) is increased. This can be done by closing material flow loops in forms such as recycling, reusing, or refurbishing of either the final products at the end of their use phase or along the supply chain, when current loss streams are reconnected to the chain, which allows valuable material to circulate within the supply chain.

Although mining is currently the dominant way of producing primary inputs for the materialized world, it tends to have a negative reputation regarding environmental and societal consequences. Undoubtedly, this is not different for phosphate rock and its large-scale operations as being one of the major global bulk commodities with mining operations in a lot of cases greatly impacting its surroundings. A more collaborative approach is needed to change the mining industry [97] as well its perception and acceptance (e.g., in the form of a Social License to Operate). In addition to more general approaches like "corporate social responsibility" or "sustainable livelihoods," various mining-related concepts such as "sustainable mining", "green mining", and "responsible mining" already exist (e.g., see [98-102]). In addition, if carried out professionally (e.g., in the form of open-minded 
environmental impact assessments), a mining operation and its related activities that impact its surroundings might be considered a rather sustainable enterprise [33]. To conclude, we must strive to establish socially acceptable mining operations since, in even the very best-case scenario, we have a long way to go to reach a state of circulation without the necessity for primary production.

\subsection{A Few Initial Steps Toward a Circular Economcy Within the Industry}

The Jorf Lasfar pipeline is a prime industrial best-practice example even though it is not the first of its kind in the phosphate industry [103] of a radical innovation in technology as well as the process layers. The slurry transport precludes the energy-intensive process step of drying the material prior to transport. Resource efficiency is increased through a reduction in transportation losses. The increased capacity in combination with massively reduced logistical costs points toward a competitive cost advantage. Ultimately, this might affect the price structure of the overall market, which requires further innovations and efficiency increment from all market participants in order to remain competitive. At first sight, this case counters our proposition of trade-offs involved in every radical innovation, but, in this case, we point to the risk dimension involved in the project. OCP S.A. claims an availability rate of $98 \%$ [82], but does not detail the events covered by it precisely. The risks of a natural disaster, human operational failures, or a terrorist attack might not be too likely, but the impact of either would be enormous and would be beyond economic losses. Potential impacts also include the contamination of surrounding soil and water or ultimately the loss of environmental licensing. Replacing a broken truck is clearly easier than replacing a broken pipeline. However, with adequate scenario planning (means of emergency pipeline repair, adequate inventory planning, etc.), the potential impact of unlikely negative factors can be minimized. In terms of transferability within the phosphate industry, potential is given for all producers, which operate their mines and beneficiation plants at a greater distance from the further downstream processing. As OCP's slurry pipeline relies on natural gravity in form of a positive altitude difference between mines and chemical processing, the applicability is strongly dependent on the geographical settings of each case. Nevertheless, the technical feasibility of steeply uphill pumping has already been shown in an iron ore installation at the Da Hong Shan pipeline in China [104].

Similar to the case above, it is difficult to identify an obvious downside to the IHP on the first sight as low-grade rock containing higher impurities can be used to produce high-quality PA without producing high-volume waste in the form of PG. The zero-grade waste is a commercial aggregate usable in the construction industries. This case clearly presents a best-practice example for a radical process innovation and even a product innovation given the preferable characteristics of the product in terms of contamination. In particular, the latter also represents a societal innovation to some extent, given the positive influence on human and animal health through the reduction of heavy-metal content. However, besides the energy intensity, REE and $U$ are bound within the aggregate emerging from the reduction kiln. Recovery of these by-products is strongly restricted. To what extent the technology will affect the market is currently rather hard to estimate since it is still in a developing stage. Nevertheless, the potential seems to be huge. In the case of Florida, the rather diminishing high-grade reserves could be massively enhanced if the cut-off grade gets lowered. The technology might also put additional capacities from countries with comparable highly-contaminated PR on the market. Australian Avenira Ltd. already holds the exclusive license for the IHP for Australia and Senegal [105].

Among the illustrated cases, seabed mining represents undoubtably the most controversial development. From the resource perspective, these additional phosphate reserves and resources might increase future supply security and reliability for important dependent countries and regions. The common belief is that, given the growing demand for PR as well as the import dependency for most countries, new reserves and producing countries could ease the future supply risk. However, in terms of overall resource availability, previous fears of a foreseeable shortage have now been shown to be unfounded $[4,106]$. In terms of geographic concentration, the application of the Herfindahl-Hirschman Index (HHI, a common measure to assess market concentration) [107], shows that, the phosphate rock sector is overall only moderately concentrated even though specific concerns have been raised. 
The societal dimension includes the possibility of increased employment opportunities but also the possible degradation of the local fishing industry, the potential need for on-shore facilities, and other unforeseen consequences of major sub-sea disturbances. Much research has been rightly focused on the environmental consequences of mining, but long-term effects are unlikely to be predictable unless long-term studies are conducted.

The tailings thickener represents another innovation with great benefits. From an economic point of view, the investment seems costly with comparably little direct returns except for water savings. However, in this case, not the direct returns, but the opportunity costs have to be considered. The investment into a technology is, besides the effects for safety and environmental benefits, particularly interesting from the aspect of potential technology transfer.

\subsection{Even When Society as a Whole Wins, Somebody Loses}

As described by Schumpeter, innovation is often related to "creative destruction." The transformation toward a $(\mathrm{P})$ circular economy requires change, which will come only at certain costs, and the latter will not be of a monetary nature only at least if we consider the respective system from a wider perspective. Yet, this does not imply an argument for pure "weak sustainability" in which environmental concerns are often sacrificed for factors such as the preservation of jobs or the decrease of energy costs [108]. Although we are not at a pareto-efficient point in mineral-resource management, we need to understand and consider the double-edged aspect of innovations. Not only just functional trade-offs but also trade-offs between agents will, most likely, always lead to someone or something being better off while, for the other side, the situation worsens to some degree. Once certain actors (or even one of the sustainability pillars) loses, its current embeddedness within value creation and issues regarding re-orientation and re-organization arise and ultimately lead to vulnerabilities within the system and/or its environment.

Sustainable and resilient mineral-resource strategies based on systemic understandings of coupled human-environmental systems should be the highest priority-and not only in import-dependent regions such as Europe. Thus, while the strategy component of substitution might work on a mid-term and a long-term for various minerals, substituting P remains impossible. Hence, strategies should be built on the best available technologies within the core supply chain as well as implications on supporting branches including health and safety, quality management, and logistics with an emphasis toward circulation.

Lastly, related to ongoing developments, industry should never turn a blind eye to global megatrends like digitalization since every innovation that keeps atoms circling in the supply chain instead of losing them (under reasonable costs of all kinds) moves us a little closer toward a circular economy.

Author Contributions: The paper emerged from the long-term cooperation of the authors within the Transdisciplinarity Laboratory Sustainable Mineral Resources at Danube University Krems. M.C.M. and L.H. contributed with their vast practical experience throughout the paper and especially in Section 3. G.S. provided the parts on innovation as well as substantial and extensive feedback to all sections. B.G. provided the basic structure and a draft for Sections 1-4. All authors collaborated on the conclusion.

Acknowledgments: We want to thank Roland W. Scholz for his valuable input and feedback and Elaine Ambrose for the thoughtful language editing of this paper. Additionally, we want to thank the three anonymous reviewers whose feedback was of incredible help to improve the article. Furthermore, we want to praise the organizational committee of the AIMS 2018 with Bernd Lottermoser leading the way, as well as all participants providing valuable feedback to our presented research.

Conflicts of Interest: The authors declare no conflicts of interest. 


\section{References}

1. De Angelis, R. Business Models in the Circular Economy; Springer: Cham, Switzerland, 2018; ISBN 978-3-319-75126-9.

2. Mew, M.C.; Steiner, G.; Geissler, B. Phosphorus Supply Chain-Scientific, Technical, and Economic Foundations: A Transdisciplinary Orientation. Sustainability 2018, 10, 1087. [CrossRef]

3. Prud'homme, M. Trends in Global Phosphate Supply. In Proceedings of the 5th Sustainable Phosphorus Summit, Kunming, China, 20-22 August 2016.

4. Scholz, R.W.; Wellmer, F.W. Although there is no Physical Short-Term Scarcity of Phosphorus, its Resource Efficiency Should be Improved: Reasons to Improve Phosphorus Resource Efficiency. J. Ind. Ecol. 2018. [CrossRef]

5. de Boer, M.A.; Romeo-Hall, A.; Rooimans, T.; Slootweg, J. An Assessment of the Drivers and Barriers for the Deployment of Urban Phosphorus Recovery Technologies: A Case Study of The Netherlands. Sustainability 2018, 10, 1790. [CrossRef]

6. Steiner, G.; Geissler, B.; Watson, I.; Mew, M.C. Efficiency developments in phosphate rock mining over the last three decades. Resour. Conserv. Recycl. 2015, 105, 235-245. [CrossRef]

7. Scholz, R.W.; Wellmer, F.W. Losses and use efficiencies along the phosphorus cycle-Part 1: Dilemmata and losses in the mines and other nodes of the supply chain. Resour. Conserv. Recycl. 2015, 105, $216-234$. [CrossRef]

8. Scholz, R.W.; Wellmer, F.W.; DeYoung, J.H. Phosphorus Losses in Production Processes Before the "“Crude Ore"' and “"Marketable Production"' Entries in Reported Statistics. In Sustainable Phosphorus Management; Scholz, R.W., Roy, A.H., Brand, F.S., Hellums, D.T., Ulrich, A.E., Eds.; Springer: Dordrecht, The Netherlands, 2014; ISBN 978-94-007-7249-6.

9. Scholz, R.W.; Geissler, B. Feebates for dealing with trade-offs on fertilizer subsidies: A conceptual framework for environmental management. J. Clean. Prod. 2018, 189, 898-909. [CrossRef]

10. Merriam-Webster Definition of Economy. Available online: https:/ /www.merriam-webster.com/dictionary/ economy (accessed on 25 July 2018).

11. Korhonen, J.; Honkasalo, A.; Seppälä, J. Circular Economy: The Concept and its Limitations. Ecol. Econ. 2018, 143, 37-46. [CrossRef]

12. European Commission. Report on Critical Raw Materials and the Circular Economy; European Commission: Brussels, Belgium, January 2018.

13. Korhonen, J.; Nuur, C.; Feldmann, A.; Birkie, S.E. Circular economy as an essentially contested concept. J. Clean. Prod. 2018, 175, 544-552. [CrossRef]

14. de Jesus, A.; Antunes, P.; Santos, R.; Mendonça, S. Eco-innovation in the transition to a circular economy: An analytical literature review. J. Clean. Prod. 2018, 172, 2999-3018. [CrossRef]

15. Prieto-Sandoval, V.; Jaca, C.; Ormazabal, M. Towards a consensus on the circular economy. J. Clean. Prod. 2018, 179, 605-615. [CrossRef]

16. Kirchherr, J.; Reike, D.; Hekkert, M. Conceptualizing the circular economy: An analysis of 114 definitions. Resour. Conserv. Recycl. 2017, 127, 221-232. [CrossRef]

17. Homrich, A.S.; Galvão, G.; Abadia, L.G.; Carvalho, M.M. The circular economy umbrella: Trends and gaps on integrating pathways. J. Clean. Prod. 2018, 175, 525-543. [CrossRef]

18. Geissdoerfer, M.; Savaget, P.; Bocken, N.M.P.; Hultink, E.J. The Circular Economy-A new sustainability paradigm? J. Clean. Prod. 2017, 143, 757-768. [CrossRef]

19. Ghisellini, P.; Cialani, C.; Ulgiati, S. A review on circular economy: The expected transition to a balanced interplay of environmental and economic systems. J. Clean. Prod. 2016, 114, 11-32. [CrossRef]

20. Merli, R.; Preziosi, M.; Acampora, A. How do scholars approach the circular economy? A systematic literature review. J. Clean. Prod. 2018, 178, 703-722. [CrossRef]

21. Winans, K.; Kendall, A.; Deng, H. The history and current applications of the circular economy concept. Renew. Sustain. Energy Rev. 2017, 68, 825-833. [CrossRef]

22. Kalmykova, Y.; Sadagopan, M.; Rosado, L. Circular economy-From review of theories and practices to development of implementation tools. Resour. Conserv. Recycl. 2018, 135, 190-201. [CrossRef]

23. Ellen MacArthur Foundation. Towards a Circular Economy: Business Rationale for an Accelerated Transition; Ellen MacArthur Foundation: Cowes, UK, December 2015; p. 20. 
24. Huy, D.; Andruleit, H.; Babies, H.-G.; Elsner, H.; Homberg-Heumann, D.; Meßner, J.; Wilken, H. Deutschland-Rohstoffsituation 2015. BGR. Available online: https://www.bgr.bund.de/DE/Themen/ Min_rohstoffe/Downloads /Rohsit-2015.pdf?_blob=publicationFile\&v=3 (accessed on 30 August 2018).

25. Geissler, B.; Mew, M.C.; Matschullat, J.; Steiner, G. The phosphate rock mining-innovation nexus. GAIA 2018. forthcoming.

26. Steiner, G. Unlock Hidden Innovation Potentials: Uncertainty, Risk, \& Opportunity Costs. In Proceedings of the IFA: Production and International Trade Conference, Paris, France, 22-24 February 2017.

27. Linkov, I.; Bridges, T.; Creutzig, F.; Decker, J.; Fox-Lent, C.; Kröger, W.; Lambert, J.H.; Levermann, A.; Montreuil, B.; Nathwani, J.; et al. Changing the resilience paradigm. Nat. Clim. Chang. 2014, 4, 407-409. [CrossRef]

28. Steiner, G. From probabilistic functionalism to a mental simulation of innovation: by collaboration from vulnerabilities to resilient societal systems. Environ. Syst. Decis. 2018, 38, 92-98. [CrossRef]

29. Schumpeter, J.A. The Theory of Economic Development; An Inquiry into Profits, Capital, Credit, Interest, and the Business Cycle; Harvard University Press: Cambridge, MA, USA, 1934; ISBN 978-0-674-87990-4.

30. Hauschildt, J.; Salomo, S.; Schultz, C.; Kock, A. Innovationsmanagement; vollständig aktualisierte und überarbeitete Auflage Verlag Franz: München, Germany, 2016; ISBN 978-3-8006-4728-6.

31. Innovations-und Technologiemanagement; Strebel, H. (Ed.) 2. erweiterte und überarbeitete Auflage; Facultas Verlags- und Buchhandels AG: Wien, Austria, 2007; ISBN 978-3-8252-2455-4.

32. Reichl, C.; Schatz, M. World Mining Data 2018; Austrian Federal Ministry of Sustainability and Tourism: Vienna, Austria, 2018.

33. Matschullat, J.; Gutzmer, J. Environmental Impacts of Mining. In Encyclopedia of Sustainability Science and Technology; Meyers, R.A., Ed.; Springer: New York, NY, USA, 2012; pp. 6633-6645. ISBN 978-0-387-89469-0.

34. Vidal, O.; Arndt, N.; Herrington, R. Metalle für Europas Industrie-Ob die Öffentlichkeit sie will oder nicht? In Rohstoffwirtschaft und Gesellschaftliche Entwicklung; Kausch, P., Matschullat, J., Bertau, M., Mischo, H., Eds.; Springer Spektrum: Berlin, Germany, 2016; pp. 3-18. ISBN 978-3-662-48854-6.

35. Commission of the European Communities. The Raw Materials Initiative-Meeting Our Critical Needs for Growth and Jobs in Europe; Communicaton from the Commission to the European Parliament and the Council; Commision of the European Communities: Brussels, Belgium, 2008; pp. 2-13.

36. Matschullat, J. Mittel- und langfristige Energie- und Rohstoffherausforderungen-Die nächsten 50 Jahre. In Rohstoffwirtschaft und gesellschaftliche Entwicklung; Kausch, P., Matschullat, J., Bertau, M., Mischo, H., Eds.; Springer Spektrum: Berlin, Germany, 2016; pp. 209-225. ISBN 978-3-662-48854-6.

37. Van Kauwenbergh, S. Cadmium in phosphate rock and fertilizers. In Proceedings of the World Fertilizer Conference, Chicago, IL, USA, 22 September 2001.

38. Scholz, R.W.; Wellmer, F.W. Challenges of sustainable (mineral) resources management and circular economics: What we can learn from the case of phosphorus? In Proceedings of the International Conference on Resource Sustainability (ICRS), Beijing, China, 27-29 June 2018.

39. Di Maio, F.; Rem, P.C.; Baldé, K.; Polder, M. Measuring resource efficiency and circular economy: A market value approach. Resour. Conserv. Recycl. 2017, 122, 163-171. [CrossRef]

40. Christmann, P. Towards a more equitable use of mineral resources. Nat. Resour. Res. 2018, 27, 159-177. [CrossRef]

41. Burlakovs, J.; Jani, Y.; Kriipsalu, M.; Vincevica-Gaile, Z.; Kaczala, F.; Celma, G.; Ozola, R.; Rozina, L.; Rudovica, V.; Hogland, M.; et al. On the way to 'zero waste' management: Recovery potential of elements, including rare earth elements, from fine fraction of waste. J. Clean. Prod. 2018, 186, 81-90. [CrossRef]

42. Ragazzi, M.; Fedrizzi, S.; Rada, E.C.; Ionescu, G.; Ciudin, R.; Cioca, L.I. Experiencing Urban Mining in an Italian Municipality towards a Circular Economy vision. Energy Procedia 2017, 119, 192-200. [CrossRef]

43. Tesfaye, F.; Lindberg, D.; Hamuyuni, J.; Taskinen, P.; Hupa, L. Improving urban mining practices for optimal recovery of resources from e-waste. Miner. Eng. 2017, 111, 209-221. [CrossRef]

44. Ma, S.; Wen, Z.; Chen, J.; Wen, Z. Mode of circular economy in China's iron and steel industry: A case study in Wu'an city. J. Clean. Prod. 2014, 64, 505-512. [CrossRef]

45. Wang, P.; Kara, S.; Hauschild, M.Z. Role of manufacturing towards achieving circular economy: The steel case. CIRP Ann. 2018, 67, 21-24. [CrossRef]

46. Yu, X. Coal mining and environmental development in southwest China. Environ. Dev. 2017, 21, 77-86. [CrossRef] 
47. Werner, T.T.; Ciacci, L.; Mudd, G.M.; Reck, B.K.; Northey, S.A. Looking Down Under for a Circular Economy of Indium. Environ. Sci. Technol. 2018, 52, 2055-2062. [CrossRef] [PubMed]

48. Bongaerts, J. A Model for the Optimal Recovery of Multiple Substances from Waste Water with a Focus on Phosphate. Sustainability 2018, 10, 2867. [CrossRef]

49. Makropoulos, C.; Rozos, E.; Tsoukalas, I.; Plevri, A.; Karakatsanis, G.; Karagiannidis, L.; Makri, E.; Lioumis, C.; Noutsopoulos, C.; Mamais, D.; et al. Sewer-mining: A water reuse option supporting circular economy, public service provision and entrepreneurship. J. Environ. Manag. 2018, 216, 285-298. [CrossRef] [PubMed]

50. de Ridder, M.; de Jong, S.; Polchar, J.; Lingemann, S. Risks and Opportunities in the Global Phosphate Rock Market-Robust Strategies in Times of Uncertainty; The Hague Centre for Strategic Studies: Haag, The Netherlands, 2012.

51. Roberts, T.L. Cadmium and Phosphorous Fertilizers: The Issues and the Science. Procedia Eng. 2014, 83, 52-59. [CrossRef]

52. Smidt, G.A.; Landes, F.C.; Machado de Carvalho, L.; Koschinsky, A.; Schnug, E. Cadmium and Uranium in German and Brazilian Phosphorous Fertilizers. In The New Uranium Mining Boom; Merkel, B., Schipek, M., Eds.; Springer: Berlin, Germany, 2011; pp. 167-175. ISBN 978-3-642-22121-7.

53. Kratz, S.; Schick, J.; Schnug, E. Trace elements in rock phosphates and P containing mineral and organo-mineral fertilizers sold in Germany. Sci. Total Environ. 2016, 542, 1013-1019. [CrossRef] [PubMed]

54. European Commission. Circular Economy: New Regulation to Boost the Use of Organic and Waste-Based Fertilisers; European Commission: Brussels, Belgium, 2016.

55. Gilbert, N. European Union Debates Controversial Plans to Limit Cadmium in Fertilizer. Available online: http:/ / www.sciencemag.org/news/2018/04/european-union-debates-controversial-plans-limitcadmium-fertilizer (accessed on 18 July 2018).

56. Wesseler, J.; Drabik, D. Economic Aspects of the Regulatory Framework in the Area of Fertilizers; Wageningen University: Wageningen, Germany, 2017.

57. Jasinski, S.M. Mineral Commodity Summaries, In Phosphate Rock; USGS: Reston, VA, USA, 2017; pp. $124-125$.

58. Wellmer, F.W.; Becker-Platen, J. Sustainable development and the exploitation of mineral and energy resources: A review. Int. J. Earth Sci. 2002, 91, 723-745.

59. CRU International. Phosphate Rock Costs; CRU International: London, UK, 2013.

60. Van Kauwenbergh, S. World Phosphate Rock Reserves and Resources; IFDC: Muscle Shoals, AL, USA, 2010.

61. Savanick, G.A. Borehole (Slurry) Mining of Coal, Uraniferous Sandstone, Oil Sands, and Phosphate Ore. United Sates Dep. Inter. 1987, 35, 1-44.

62. Hrabik, J.A.; Godesky, D.J. Economic Evaluation of Borehole and Conventional Mining Systems in Phosphate Deposits; University of Michigan Library: Ann Arbor, MI, USA, 1983.

63. Marvasti, A. Reserve characteristics and mining costs-An empirical study of the phosphate industry. Environ. Resour. Econ. 1996, 7, 357-373. [CrossRef]

64. Asri, M.; Daafi, Y. Application of Cast Blasting in Moroccan Phosphate Mines. Procedia Eng. 2016, 138, $56-63$. [CrossRef]

65. Albuquerque, R.O.; Peres, A.E.C.; Aquino, J.A.; Praes, P.E.; Pereira, C.A. Pilot Scale Direct Flotation of a Phosphate Ore with Silicate-Carbonate Gangue. Procedia Eng. 2012, 46, 105-110. [CrossRef]

66. Bittner, J.D.; Hrach, F.J.; Gasiorowski, S.A.; Canellopoulus, L.A.; Guicherd, H. Triboelectric Belt Separator for Beneficiation of Fine Minerals. Procedia Eng. 2014, 83, 122-129. [CrossRef]

67. Gallala, W.; Herchi, F.; Ali, I.B.; Abbassi, L.; Gaied, M.E.; Montacer, M. Beneficiation of Phosphate Solid Coarse Waste from Redayef (Gafsa Mining Basin) by Grinding and Flotation Techniques. Procedia Eng. 2016, 138, 85-94. [CrossRef]

68. Hakkou, R.; Benzaazoua, M.; Bussière, B. Valorization of Phosphate Waste Rocks and Sludge from the Moroccan Phosphate Mines: Challenges and Perspectives. Procedia Eng. 2016, 138, 110-118. [CrossRef]

69. Statista Top Mining Companies Total Revenue 2017. Available online: https:/ /www.statista.com/statistics / 208715/total-revenue-of-the-top-mining-companies/ (accessed on 19 July 2018).

70. PwC. Mine 2017 Stop. Think... Act. Available online: https://www.pwc.com/gx/en/industries/energyutilities-resources / publications/mine-2017.html (accessed on 19 July 2018).

71. Auty, R.M. Sustaining Development in Mineral Economies the Resource Curse Thesis; Routledge: London, UK, 1993; ISBN 978-0-415-09482-5. 
72. Frankel, J.A. The Natural Resource Curse: A Survey. 2010. Available online: http:/ /www.nber.org/papers / w15836.pdf (accessed on 30 August 2018).

73. Geissler, B.; Mew, M.C.; Weber, O.; Steiner, G. Efficiency performance of the world's leading corporations in phosphate rock mining. Resour. Conserv. Recycl. 2015, 105, 246-258. [CrossRef]

74. Zhang, P. Comprehensive Recovery and Sustainable Development of Phosphate Resources. Procedia Eng. 2014, 83, 37-51. [CrossRef]

75. Gabriel, S.; Baschwitz, A.; Mathonnière, G.; Fizaine, F.; Eleouet, T. Building future nuclear power fleets: The available uranium resources constraint. Resour. Policy 2013, 38, 458-469. [CrossRef]

76. Haneklaus, N.; Sun, Y.; Bol, R.; Lottermoser, B.; Schnug, E. To Extract, or not to Extract Uranium from Phosphate Rock, that is the Question. Environ. Sci. Technol. 2017, 51, 753-754. [CrossRef] [PubMed]

77. Ellen MacArthur Foundation; Foundation for Environmental Economics and Sustainability; McKinsey Center for Business and Environment. Growth Within: A Circular Economy Vision for a Competitive Europe; Ellen MacArthur Foundation: Cowes, UK, 2015.

78. Hermann, L.; Kraus, F.; Hermann, R. Phosphorus Processing—Potentials for Higher Efficiency. Sustainability 2018, 10, 1482. [CrossRef]

79. Wellmer, F.W. Nachhaltigkeit und Rohstoffgewinnung-ein Widerspruch? Sustainability and Exploitation of Raw Materials-A Contradiction? Erdöl Erdgas Kohle 2016, 46-85.

80. Bhabra, H. Slurry pipeline now goes the distance. World Pumps 2013, 2013, 38-40. [CrossRef]

81. Rusconi, J.; Lakhouaja, A.; Kopuz, M. The Design and Engineering of the $187 \mathrm{~km}$ Khouribga to Jorf Lasfar Phosphate Slurry Pipeline. Procedia Eng. 2016, 138, 142-150. [CrossRef]

82. OCP, S.A. The Slurry Pipeline Revolution. Available online: http://www.ocpgroup.ma/sites/default/files / alldocs/slurry_pipeline-revolution_uk.pdf (accessed on 2 February 2018).

83. KEM Works Technology Inc. A Technical Review of the Improved Hard Process. In Proceedings of the Fertiliser Association of India International Technical Conference, New Delhi, India, 21-22 April 2011.

84. Blake, D. The Improved Hard Process: Current status and Next Steps. 2017. Available online: https:/ / www. avenira.com/wp-content/uploads/2017/03/JDC-Phosphate-David-Blake.pdf (accessed on 2 February 2018).

85. Fowler, T. Personal conversation with Tip Fowler, Director of Business Development. Personal Communication, 17 August 2017.

86. Hannington, M.; Petersen, S.; Krätschell, A. Subsea mining moves closer to shore. Nat. Geosci. 2017, 10, 158-159. [CrossRef]

87. Watson, I.; van Straaten, P.; Katz, T.; Botha, L. Mining and Concentration: What Mining to What Costs and Benefits? In Sustainable Phosphorus Management; Scholz, R.W., Roy, A.H., Brand, F.S., Hellums, D.T., Ulrich, A.E., Eds.; Springer: Dordrecht, The Netherlands, 2014; pp. 153-182. ISBN 978-94-007-7249-6.

88. Geissler, B.; Steiner, G. Interactive comment on “Comment on: 'Recent revisions of phosphate rock reserves and resources: A critique' by Edixhoven et al. (2014)_Phosphate reserves and resources: What conceptions and data do stakeholders need for sustainable action?" by R. W. Scholz and F.-W. Wellmer. Earth Syst. Dynam. Discuss. 2015, 6, C56-C68.

89. Namib Times Namibia Marine Phosphate Comes out of Its Corner. Available online: http:/ / namibtimes. net/namibia-marine-phosphate-comes-out-of-its-corner / (accessed on 31 July 2017).

90. Smit, E. Phosphate Mining Gets Green Light. Available online: http://www.met.gov.na/news/159/ phosphate-mining-gets-green-light (accessed on 31 July 2017).

91. The Directors and Management of the Namibian Marine Resources (PTY) Ltd. Official Media Statement \#6. Available online: https:/ / www.google.com.tw/url?sa=t\&rct=j\&q=\&esrc=s\&source=web\&cd=1\&ved= 2ahUKEwjWyv359KXdAhUN9bwKHffBBQAQFjAAegQIBBAC\&url=https\%3A\%2F\%2Fwww.namphos. com\%2Fvideos\%2Fmedia-releases\%2Fitem\%2Fdownload\%2F38_f071292e5c842060a65193092d5a3695. html\&usg=AOvVaw2uVrvVtJKc2zc8S9Nqj0xR (accessed on 2 February 2017).

92. Levin, L.A.; Mengerink, K.; Gjerde, K.M.; Rowden, A.A.; Van Dover, C.L.; Clark, M.R.; Ramirez-Llodra, E.; Currie, B.; Smith, C.R.; Sato, K.N.; et al. Defining "serious harm" to the marine environment in the context of deep-seabed mining. Mar. Policy 2016, 74, 245-259. [CrossRef]

93. Phillips, D. Brazil Dam Disaster: Firm Knew of Potential Impact Months in Advance; The Guardian: London, UK, 2018. 
94. Outotec. Europe's Largest Paste Plant Extends Lifespan of Yara's Tailings Storage Facility. Available online: http://www.outotec.com/company/newsletters/minerva/minerva--3--2017/europes-largestpaste-plant-extends-lifespan-of-yaras-tailings-storage-facility/ (accessed on 27 July 2018).

95. Outotec. Thickeners or Thickener Plants-Optimizing the Performance and Cost of Thickened Tailings. Available online: https://www.outotec.com/company/newsletters/minerva/minerva-issue-3--2017/ thickeners-or-thickener-plants--optimizing-the-performance-and-cost-of-thickened-tailings / (accessed on 27 July 2018).

96. Outotec. Enhanced Paste Plant Control with Act Thickener Optimizer at Yara Siilinjärvi. Available online: https: / www.outotec.com/globalassets / newsletters / output/2018-1/2.-yara-act-thickener-optimizer_ case-study.pdf (accessed on 27 July 2018).

97. Batterham, R. Lessons in Sustainability from the Mining Industry. Procedia Eng. 2014, 83, 8-15. [CrossRef]

98. Nurmi, P. Green Mining-A Holistic Concept for Sustainable and Acceptable Mineral Production. Ann. Geophys. 2017, 60, 1-7. [CrossRef]

99. Broad, R. Responsible mining: Moving from a buzzword to real responsibility. Extr. Ind. Soc. 2014, 1, 4-6. [CrossRef]

100. Dimmler, L. Linking social determinants of health to corporate social responsibility: Extant criteria for the mining industry. Extr. Ind. Soc. 2017, 4, 216-226. [CrossRef]

101. Horsley, J.; Prout, S.; Tonts, M.; Ali, S.H. Sustainable livelihoods and indicators for regional development in mining economies. Extr. Ind. Soc. 2015, 2, 368-380. [CrossRef]

102. Prno, J.; Slocombe, D.S. A Systems-Based Conceptual Framework for Assessing the Determinants of a Social License to Operate in the Mining Industry. Environ. Manag. 2014, 53, 672-689. [CrossRef] [PubMed]

103. Simplot Phosphates, LLC. Simplot Agribusiness 2018. Available online: http://www.simplot.com/pdf/us_ operations/Phosphates.pdf (accessed on 30 August 2018).

104. International Mining. Mine Slurry Transport. Available online: https://im-mining.com/2011/04/01/mineslurry-transport/ (accessed on 30 August 2018).

105. Avenira Ltd. JDC Phosphate (Avenira-c.7\%). Available online: https:/ /www.avenira.com/other-projects / jdc-phosphate. (accessed on 30 August 2018).

106. Edixhoven, J.D.; Gupta, J.; Savenije, H.H.G. Recent revisions of phosphate rock reserves and resources: Reassuring or misleading? An in-depth literature review of global estimates of phosphate rock reserves and resources. Earth Syst Dynam Discuss 2013, 4, 574-598. [CrossRef]

107. Geissler, B.; Steiner, G.; Mew, M.C. Clearing the fog on phosphate rock data-Uncertainties, fuzziness, and misunderstandings. Sci. Total Environ. 2018, 642, 250-263. [CrossRef] [PubMed]

108. Tost, M.; Hitch, M.; Chandurkar, V.; Moser, P.; Feiel, S. The state of environmental sustainability considerations in mining. J. Clean. Prod. 2018, 182, 969-977. [CrossRef] 